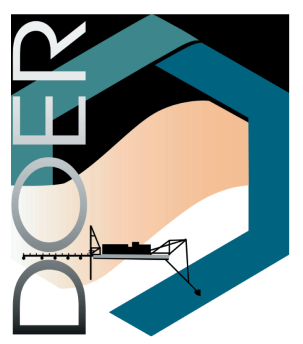

\title{
Assessment of Potential Impacts of Dredging Operations Due to Sediment Resuspension
}

PURPOSE: This technical note summarizes the known biological responses of estuarine and coastal fish and shellfish to suspended sediments and relates these findings to suspended-sediment conditions associated with dredging projects. An objective approach toward evaluation of sediment resuspension impacts is proposed that requires full consideration of (a) the existing state of knowledge concerning the effects of suspended sediments on fish and shellfish, including recognition of the gaps therein, and (b) concentration-exposure duration combinations likely to be encountered by organisms in the vicinity of dredging operations. This note focuses upon the exposure of organisms to sediments in the water column. Effects of deposited sediments will be treated separately.

INTRODUCTION: Estuarine and coastal organisms are exposed to suspended sediments from storms, tidal flows, and currents and therefore have behavioral and physiological mechanisms for dealing with this feature of their habitat. Because dredging-related suspended-sediment plumes may differ in scope, timing, duration, and intensity from natural conditions, dredging may create conditions not typically experienced by resident or transient species. Assessing how dredgingrelated suspended-sediment conditions may affect organisms requires knowledge of (a) the thresholds at which relevant life history stages of organisms respond negatively to suspended sediments, (b) reliable estimates of dredging-induced suspended-sediment plume temporal and spatial dynamics, and (c) the probability that organisms encountering a dredging-related suspendedsediment plume will exceed a concentration and/or exposure duration tolerance threshold.

The literature concerning suspended-sediment effects on aquatic fauna has been periodically reviewed (e.g., Morton 1977; Moore 1978; Priest 1981; Kerr 1995). However, until recently, there has been little attempt to assess environmental impacts with models that can be easily used by resource managers (Newcombe and MacDonald 1991). Simplified models have been developed to predict suspended-sediment impacts on freshwater fishes (Newcombe and MacDonald 1991; Gregory, Servizi, and Martens 1993; MacDonald and Newcombe 1993) and were expanded to include estuarine fishes (Newcombe and Jensen 1996). Historically, suspended-sediment impacts were considered to be a function of concentration; i.e., most experimental studies used concentration alone as the variable of interest, and exposure durations were not varied and in many cases not reported (Sherk and Cronin 1970; LaSalle et al. 1991). Regulatory controls on suspended-sediment impacts also focused on concentration thresholds. More recently the duration of exposure to suspended sediments has been emphasized as another important factor. Concentration alone is poorly correlated with the responses of salmonid fish to suspended sediments, whereas dosage (measured as $\mathrm{mg} \mathrm{h}^{-1}$ ) is more strongly associated with fish responses (Newcombe and MacDonald 1991).

Newcombe and Jensen (1996) recognized the utility of "look-up tables" that can be used in the field or as an easy reference to predict suspended-sediment impacts on biological resources. This 
technical note modified their approach, which examines suspended-sediment impacts in a nonspecific manner, by graphing biological responses as a function of suspended-sediment concentrations and durations of exposure. This approach facilitates treatment of suspended-sediment effects likely to occur in association with dredging projects, as illustrated by relevant data for estuarine fish and shellfish. Data are included from identified studies that reported suspended-sediment concentrations, exposure durations, and a description of the responses of the organisms by taxonomic group and life history stage. Response categories included the following effects: none, behavioral, sublethal, and different percentages of mortality. Descriptive accounts of fish and shellfish responses under various conditions are also given in cases where studies omitted either suspendedsediment concentrations or durations of exposure, or measured turbidity (Nephelometric Turbidity Units (NTUs) or Jackson Turbidity Units (JTUs)) rather than suspended-sediments (mg/L). Impacts related to low dissolved oxygen levels and the release of contaminants are summarized by LaSalle (1990) and are not addressed in this review. In addition, an extensive review of the salmonid literature (treated extensively by Newcombe and Jensen 1996), which pertains largely to salmonid responses in freshwater habitats, was not included. Other anadromous fish, however, are included. The habitat types represented in laboratory experiments are noted in Table 1.

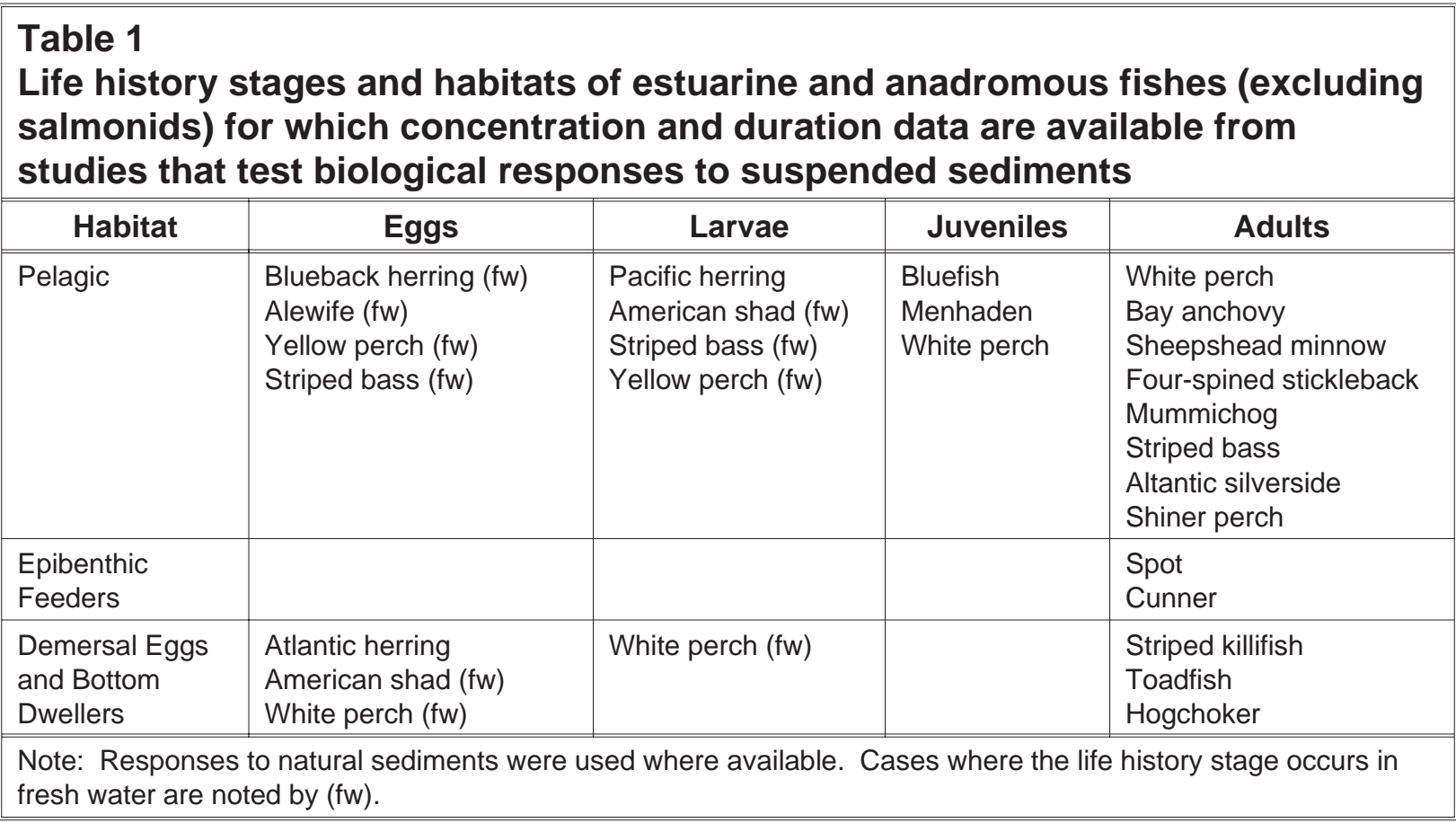

A variety of particulate matter including natural silt, Fuller's earth, kaolin clay, incinerator residue, charcoal, silica, and volcanic ash has been used to test fish and shellfish responses to suspended sediments. In studies where natural sediments were tested in addition to other sediment types, the results of the natural sediment tests were used in this review. Because a broad range of species were tested with Fuller's earth by Sherk et al. (1974), these results are included in this review along with those elicited by natural sediments. 


\section{BIOLOGICAL RESPONSES TO SUSPENDED-SEDIMENTS}

\section{Estuarine and Coastal Fish Eggs and Larvae}

Hatching Success. The eggs and larvae of estuarine and coastal fish exhibit some of the most sensitive responses to suspended-sediment exposures of all the taxa and life history stages for which data are available. Hatching is delayed for striped bass (Morone saxatilis) and white perch ( $M$. americana) eggs at concentrations of $100 \mathrm{mg} / \mathrm{L}$ for a 1-day exposure. These species release eggs in freshwater habitats. Egg development of Atlantic herring (Clupea harengus), an oceanic spawner, was not impaired by suspended-sediment dosages of 300 and $500 \mathrm{mg} / \mathrm{L}$ for 1 day (Kiorboe et al. 1981). Messieh, Wildish, and Peterson (1981) reported that although burial of Atlantic herring eggs under even a thin veneer of sediment caused substantial mortality, direct exposure to suspended-sediment concentrations as high as $7,000 \mathrm{mg} / \mathrm{L}$ had no observable effect on hatching success.

Direct Mortality. Mortality occurred at relatively low suspended-sediment concentrations sustained for several days for the larvae of anadromous fish that occur in freshwater and brackish habitats at this life history stage. Striped bass, American shad (Alosa sapidissima), yellow perch (Perca flavescens), and white perch larvae exhibited increased mortality at suspended-sediment dosages less than or equal to $500 \mathrm{mg} / \mathrm{L}$ for 4 days (3 days for striped bass) (Auld and Schubel 1978). Pacific herring ( $C$. harengus pallasi), which has an estuarine larval form, reduced feeding at a suspended-sediment dosage of 2,000 mg/L for one day (Boehlert and Morgan 1985), whereas Atlantic herring larvae reared at concentrations above $540 \mathrm{mg} / \mathrm{L}$ tended to be small, and those exposed to 19,000 mg/L for $48 \mathrm{hr}$ suffered 100 percent mortality (Messieh, Wildish, and Peterson 1981).

\section{Estuarine and Coastal Juvenile and Adult Fish}

Behavioral Responses. Foraging patterns and success are commonly studied behavioral responses of estuarine fish to suspended sediments. Turbid water reduced feeding in adult Atlantic croaker (Micropogonias undulatus) and pinfish (Lagodon rhomboides) (Minello, Zimmerman, and Martinez 1987). Feeding rates of the silverside (Atherina breviceps) were also significantly reduced at a high turbidity level (120 NTU), presumably due to a decrease in the reactive distance of the fish to their planktonic prey, which can occur at turbidities as low as 28 NTU (Hecht and van der Lingen 1992).

Sublethal Responses. Sherk, O'Connor, and Neumann (1975) and Sherk et al. (1974) have conducted the most extensive bioassays of suspended-sediment impacts on estuarine fishes, however only for short exposures. They assessed sublethal effects of fuller's earth suspensions by measuring blood cell counts, hemoglobin levels, blood ionic composition, carbohydrate utilization, and gill histology. Common sublethal responses were increased red cell counts, hematocrit levels, and hemoglobin concentrations in the peripheral blood, all of which are consistent with the responses of fish deprived of oxygen (O'Connor, Neumann, and Sherk 1976). Fine particles coated the respiratory epithelia of the fish, which hindered gas exchange with the water. Larger sediment particles were trapped by the gill lamellae and blocked the passage of water, leading to asphyxiation. 
The lowest concentration $\times$ duration dosage that elicited a sublethal response occurred at $650 \mathrm{mg} / \mathrm{L}$ for 5 days exposure, causing elevated hematocrit levels in white perch (Sherk et al. 1974). The longest duration for which responses to suspended sediments were available for estuarine fish is 14 days, which at a concentration of $1,500 \mathrm{mg} / \mathrm{L}$, caused elevated hematocrit levels in striped bass (Figure 1).

Lethal Responses. Sherk, O'Connor, and Neumann (1975) and Sherk et al. (1974) used fuller's earth to generate mortality curves (lethal concentrations that produce 10, 50, and 90 percent mortality rates $\left(\mathrm{LC}_{10}, \mathrm{LC}_{50}, \mathrm{LC}_{90}\right)$ ) for six species: white perch, spot (Leiostomus xanthurus), Atlantic silversides (Menidia menidia), bay anchovies (Anchoa mitchelli), mummichogs (Fundulus heteroclitus), and striped killifish (F. majalis). Other species were also tested for suspendedsediment tolerances, but concentration-dependent mortality curves were not determined. Based on the results of these tests, fish were classified as either tolerant $(24 \mathrm{hr} \mathrm{LC} 10>10,000 \mathrm{mg} / \mathrm{L})$, sensitive $\left(\mathrm{LC}_{10}<10,000>1,000 \mathrm{mg} / \mathrm{L}\right)$, or highly sensitive $\left(\mathrm{LC}_{10}<1,000 \mathrm{mg} / \mathrm{L}\right)$ to suspensions of fuller's earth. The tolerant species were the mummichog, striped killifish, spot, toadfish (Opsanus tau), hogchoker (Trinectes maculatus), and cusk eel (Rissola marginata), all of which commonly occur near the substrate-water interface where suspended-sediment concentrations tend to be highest. White perch, bay anchovy, juvenile menhaden (Brevoortia tyrannus), striped bass, Atlantic croaker, and weakfish (Cynoscion regalis) were classified as sensitive species. This grouping of fish did not share a particular habitat preference. Highly sensitive species included Atlantic silversides, juvenile bluefish (Pomatomus saltatrix), and young-of-the-year white perch.

The accumulated data from studies of estuarine and coastal fish are largely limited to effects of exposures between 1 and 11 days, at concentrations between 100 and 10,000 mg/L (Figure 1). Responses are highly species-specific, with lethal effects observed at dosages as low as several hundred $\mathrm{mg} / \mathrm{L}$ for $24 \mathrm{hr}$, or no effect at concentrations above 10,000 mg/L for 7 days. Atlantic silversides and white perch were among the estuarine fish with the most sensitive lethal responses to suspended-sediment exposures, exhibiting 10 percent mortality at concentrations less than 1,000 $\mathrm{mg} / \mathrm{L}$ for 1- and 2-day durations, respectively. The lethal effects of natural muds were tested for white perch, killifish, and spot, and in general, higher concentrations of natural muds were required to elicit the same mortality level that occurred when fuller's earth was used for equivalent exposure durations (Sherk, O’Connor, and Neumann 1975; Sherk et al. 1974).

\section{Estuarine and Coastal Shellfish}

Egg and Larval Stages. The effects of suspended sediments on bivalve egg survival have been investigated for the eastern oyster (Crassostrea virginica) (Davis 1960) and hard clams (Mercenaria mercenaria) (Davis and Hidu 1969) (Table 2). Although the duration of exposure to various suspended-sediment concentrations was not given in these studies, it is known that the egg stage lasts only several hours for oysters (Cake 1983) and about $12 \mathrm{hr}$ for clams (Mulholland 1984). These investigators measured the percentage of eggs that developed to the straight-hinged larval stage. Negative impacts to oyster egg development occurred at $188 \mathrm{mg} / \mathrm{L}$ of silt, compared with 1,000 $\mathrm{mg} / \mathrm{L}$ for clam eggs. Larval development continued normally at suspended-sediment concentrations less than $750 \mathrm{mg} / \mathrm{L}$, whereas higher concentrations for durations of 10 and 12 days consistently had lethal effects for clams and oysters, respectively. 

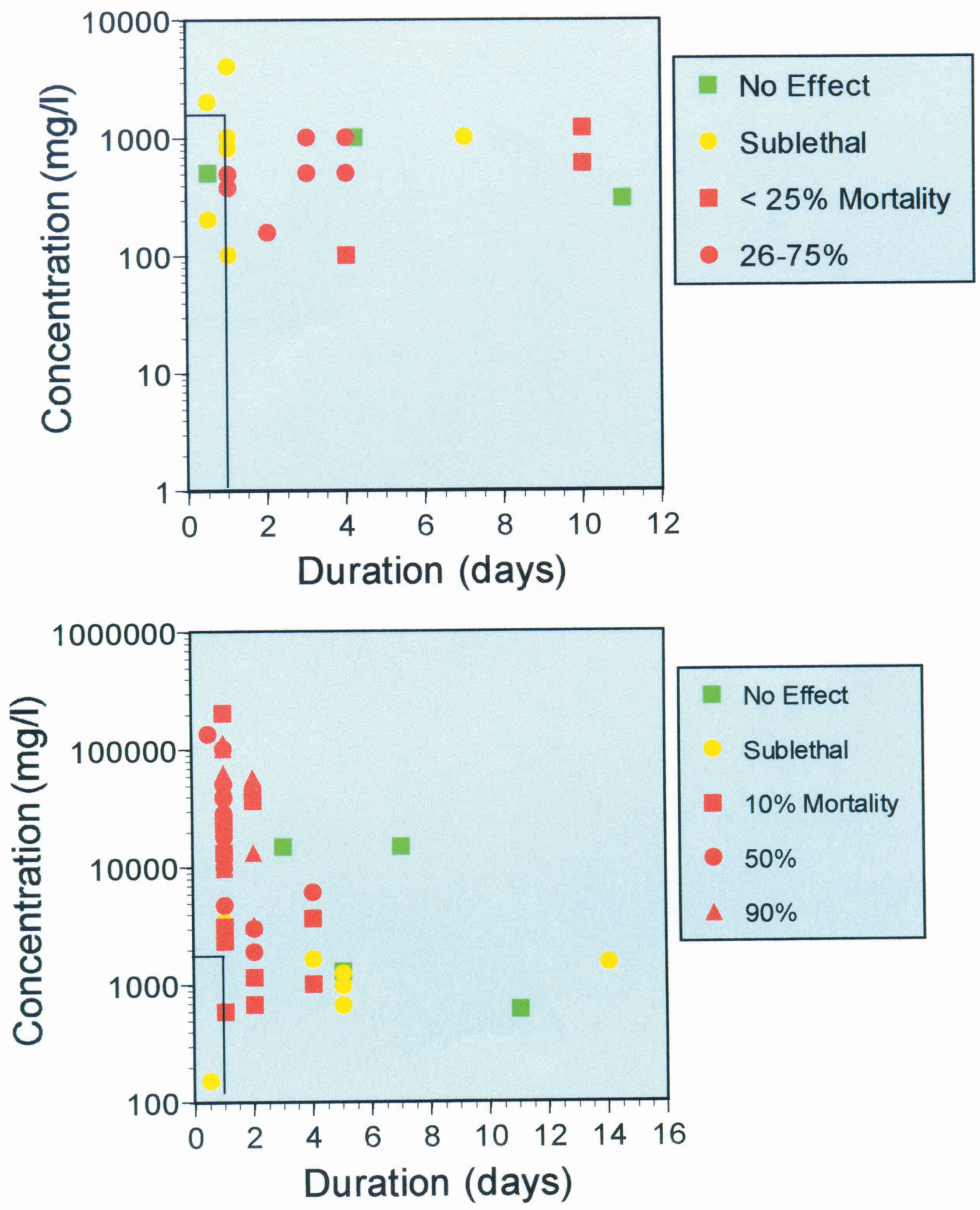

Figure 1. Responses of estuarine and anadromous fish eggs and larvae (top) and adults (bottom) to suspended-sediment concentrations at the given dosages. The area within the rectangles depicts a probable dosage range associated with most dredging operations 


\begin{tabular}{|l|l|l|l|l||}
\hline \hline $\begin{array}{l}\text { Table } 2 \\
\text { Life history stages and habitats of shellfish that have been tested for biological } \\
\text { responses to suspended sediment dosages (see Table 1) }\end{array}$ \\
\hline \hline \multicolumn{1}{|c|}{ Habitat } & \multicolumn{1}{|c||}{ Eggs } & \multicolumn{1}{|c||}{ Larvae } & \multicolumn{1}{c||}{ Juveniles } & \multicolumn{1}{c||}{ Adults } \\
\hline \hline Pelagic & $\begin{array}{l}\text { Eastern oyster } \\
\text { Hard clam }\end{array}$ & $\begin{array}{l}\text { Eastern oyster } \\
\text { Pacific oyster } \\
\text { Hard clam }\end{array}$ & & Mysid shrimp \\
\hline $\begin{array}{l}\text { Benthic and } \\
\text { Mobile }\end{array}$ & & $\begin{array}{l}\text { Shrimp (P. japonicus) } \\
\text { Dungeness crab }\end{array}$ & $\begin{array}{l}\text { Spot-tailed sand shrimp } \\
\text { Black-tailed sand shrimp } \\
\text { Grass shrimp } \\
\text { Dungeness crab }\end{array}$ \\
\hline $\begin{array}{l}\text { Demersal Eggs } \\
\text { and Sessile } \\
\text { Organisms }\end{array}$ & & $\begin{array}{l}\text { Coast mussel } \\
\text { Blue mussel } \\
\text { Hard clams }\end{array}$ & $\begin{array}{l}\text { Coast mussel } \\
\text { Blue mussel } \\
\text { Eastern oyster } \\
\text { Soft-shell clam } \\
\text { Hard clam } \\
\text { Surf clam } \\
\text { Bay scallop }\end{array}$ \\
\hline
\end{tabular}

\section{Juvenile and Adult Stages}

Bivalve Molluscs. Primary mechanisms used by bivalves to deal with high suspended-sediment concentrations include the reduction of net pumping rates (Foster-Smith 1976) and rejection of excess filtered material as pseudofeces (Robinson, Wehling, and Morse 1984; Turner and Miller 1991; Hawkins et al. 1996). When suspended-sediment concentrations rise above a threshold at which bivalves can effectively filter material, a dilution of the available food occurs (Widdows, Fieth, and Worrall 1979). The responses of suspension-feeding bivalves to relatively low suspended-sediment concentrations are varied. Mussels (Mytilus edulis) (Kiorboe, Mohlenberg, and Nohr 1981), surf clams (Spisula subtruncata) (Mohlenberg and Kiorboe 1981), and eastern oysters (Urban and Langdon 1984) exhibit increased growth rates in high algal concentrations after the addition of silt. Hard clams, however, decrease their algal ingestion with increasing sediment loads (Bricelj and Malouf 1984), resulting in no difference in their growth rates compared with those of clams exposed to an algal diet alone (Bricelj, Malouf, and De Quillfeldt 1984). The presence of suspended clay $(20 \mathrm{mg} / \mathrm{L})$ interferes with the ability of juvenile eastern oysters to preferentially ingest algae, but does not reduce the overall amount of algae ingested (Urban and Kirchman 1992). The summer growth of European oysters (Ostrea edulis) in the field was enhanced at low levels of sediment resuspension and inhibited as sediment deposition increased (Grant, Enright, and Griswold 1990). Sediment chlorophyll in suspension at low levels may act as a food supplement, thus enhancing growth, but at higher concentrations may dilute planktonic food resources and suppress food ingestion.

The progression of sublethal effects associated with relatively low concentrations is demonstrated by soft-shelled clams (Mya arenaria) exposed to suspended sediments in the 100- to 200-mg/L range. The clams first exhibit reduced gape width and partial retraction of their siphons and mantles over the first 7 days of exposure, a decreased response to mechanical stimuli by 15 days, and prolonged protrusion of their siphons by day 30 (Grant and Thorpe 1991). In laboratory studies, 
lethal concentrations for adult bivalves exposed for as long as 3 weeks were in the realm of fluid mud, i.e., around 10,000 mg/L. Data concerning responses to longer term exposures were not available.

Crustaceans: The suspended-sediment tolerances of crustaceans have not been the focus of many laboratory studies (Table 2). Most studies recorded the concentration of suspended sediments required to induce mortality over durations of days to weeks. In experiments that lasted up to 2 weeks, nearly all mortality was caused by concentrations of suspended sediments that exceeded $10,000 \mathrm{mg} / \mathrm{L}$. The majority of these mortality levels were less than 25 percent, even at very high concentrations. None of the crustaceans tested exhibited negative responses at dosages within the realm of suspended-sediment conditions associated with dredging projects.

Turbid estuarine waters may provide refuge from predation for juvenile shrimp, which are heavily preyed upon by estuarine fishes. Brown (Peneaus aztecus) and white (P. setiferus) shrimp are common over a wide range of turbidities, whereas pink shrimp ( $P$. duorarum) are most abundant in areas with low turbidity levels. Juvenile penaeid shrimp burrow in sandy sediments during the day and emerge at night to forage. In experimental aquaria, predation by Atlantic croaker and pinfish on juvenile shrimp was reduced in turbid water, whereas the predation efficiency of the southern flounder (Paralichthys lethostigma), an ambush predator, was increased (Minello, Zimmerman, and Martinez 1987).

\section{DREDGING-RELATED SUSPENDED-SEDIMENT PLUMES}

Spatial Scales of Exposure. Spatio-temporal dynamics and concentration gradients within suspended-sediment plumes are dependent on numerous factors, including specific dredge plant, in situ sediment characteristics, and environmental conditions at the time of dredging (Havis 1988; McLellan et al. 1989; Herbich and Brahme 1991; Collins 1995). While predictions of suspendedsediment conditions for dredging projects in locations other than where field data have been collected yield variable results (Johnson and Parchure 1999), the relative impacts of different types of dredges and the concentrations of suspended sediments associated with each can be generalized. For instance, mechanical dredges (e.g., bucket or clamshell) are associated with higher suspendedsediment concentrations than hydraulic (hopper and cutterhead) methods. Mechanical dredges generate suspended-sediments through the impact of the bucket on the bottom and withdrawal from the bottom, washing of material out of the bucket as it moves through the water column and above the water surface, and additional loss when the barge is loaded (LaSalle 1990). Mechanical dredges are commonly used for small projects near docks and piers or where rocky deposits are present (Morton 1977) and can be used more easily at greater depths than hydraulic methods. A suspendedsediment plume associated with clamshell dredging at its maximum concentration $(1,100 \mathrm{mg} / \mathrm{L})$ may extend up to 1,000 $\mathrm{m}$ on the bottom (Havis 1988; LaSalle 1990; Collins 1995).

Temporal Scales of Exposure. Although many factors such as weather and hydrodynamic conditions, sediment type, and dredge operator skill interact to affect the progress of a dredging operation, the average advance rate of a given dredge can be estimated based on existing information. For example, an average advance rate of $12-18 \mathrm{~m} / \mathrm{hr}$ for clamshell dredging projects in the Mobile 
District ${ }^{1}$ can be used to estimate that a stationary point along a navigation channel would fall within the boundaries of a 1,000-m suspended-sediment plume (although most dredging plumes are typically less than $500 \mathrm{~m}$ ) for approximately 2.8 to 4.3 days. The actual suspended-sediment exposure experienced by sessile organisms may be highly variable depending on the hydrodynamic conditions of the area near the dredging site. Tidal flushing may alleviate exposures to the plume for periods of hours. Alternatively, a fluff zone may be established in which the settling of particles is inhibited as suspended-sediment concentrations in the lower water column increase. This fluff zone may continue to exist for a few weeks following the termination of the dredging project (Wakeman, Peddicord, and Sustar 1975), but is less likely to persist in shallow waters adjacent to the channel.

Hydraulic dredges mix large volumes of water with sediments to form a slurry that is either pumped through a pipeline or into a hopper bin for discharge at a placement site or sidecast away from the dredging site (Morton 1977). The rate of cutterhead rotation, vertical thickness of the dredge cut, and swing rate of the dredge all affect turbidities generated by the dredging project (LaSalle 1990). Based on total volume of dredged material produced annually, hydraulic cutterhead plants are the most common dredging method used in the continental United States. Maximum concentrations generally remain less than $500 \mathrm{mg} / \mathrm{L}$ and bottom suspended-sediment plumes are limited to within $500 \mathrm{~m}$ of the dredge (Havis 1988; LaSalle 1990). Advance rates for cutterhead dredges vary by pipeline size and sediment type, but range from approximately $6 \mathrm{~m} / \mathrm{hr}$ for $0.5-$ to $0.6-\mathrm{m}$ (20- to 24-in.) pipeline dredges pumping sands to $18 \mathrm{~m} / \mathrm{hr}$ for 0.7 - to $0.8-\mathrm{m}$ (27- to 30-in.) pipeline dredges pumping silty material. ${ }^{1}$ Knowledge of dredge production and advance rates can be used to estimate duration of plumes at a fixed point along a navigation channel. For example, hypothetical exposures to suspended-sediment plumes generated by cutterhead dredging for sessile benthic organisms immediately adjacent to the channel may last from approximately 1 to 3.5 days or longer (Figure 2) depending on the project conditions and a variety of other factors.

Hopper dredges are self-contained vessels resembling barges that can maintain speeds of up to $3.6 \mathrm{~m} / \mathrm{sec}$ (7 knots) while dredging (Morton 1977). Bottom turbidity associated with hopper dredges is caused by the dragheads as they are pulled through bottom sediments. Surface turbidity may be substantial if overflow occurs from the hoppers during loading, a practice that increases the sediment content in the hopper bins (LaSalle 1990). Suspended-sediment plumes may range up to 1,200 $\mathrm{m}$ on the bottom at concentrations up to $800 \mathrm{mg} / \mathrm{L}$. Surface concentrations are dependent on whether overflow is occurring.

INTEGRATING BIOLOGICAL AND DREDGING PROJECT DATA: It is a challenge to integrate biological and engineering information to objectively evaluate potential impacts to a given resource and to reach a consensus on such measures to protect that resource as environmental windows. The basic problem, with respect to suspended sediments, is portrayed in its simplest form in Figure 3. Given the project-specific conditions of a dredge plant, in situ sediment characteristics, local hydrodynamics, and distributions of resources in space and time, exposures can be conceived to fall within a matrix of concentration/duration combinations. Clearly those projects causing minimal resuspension for short time intervals pose minimal risk of exposure above specific response 


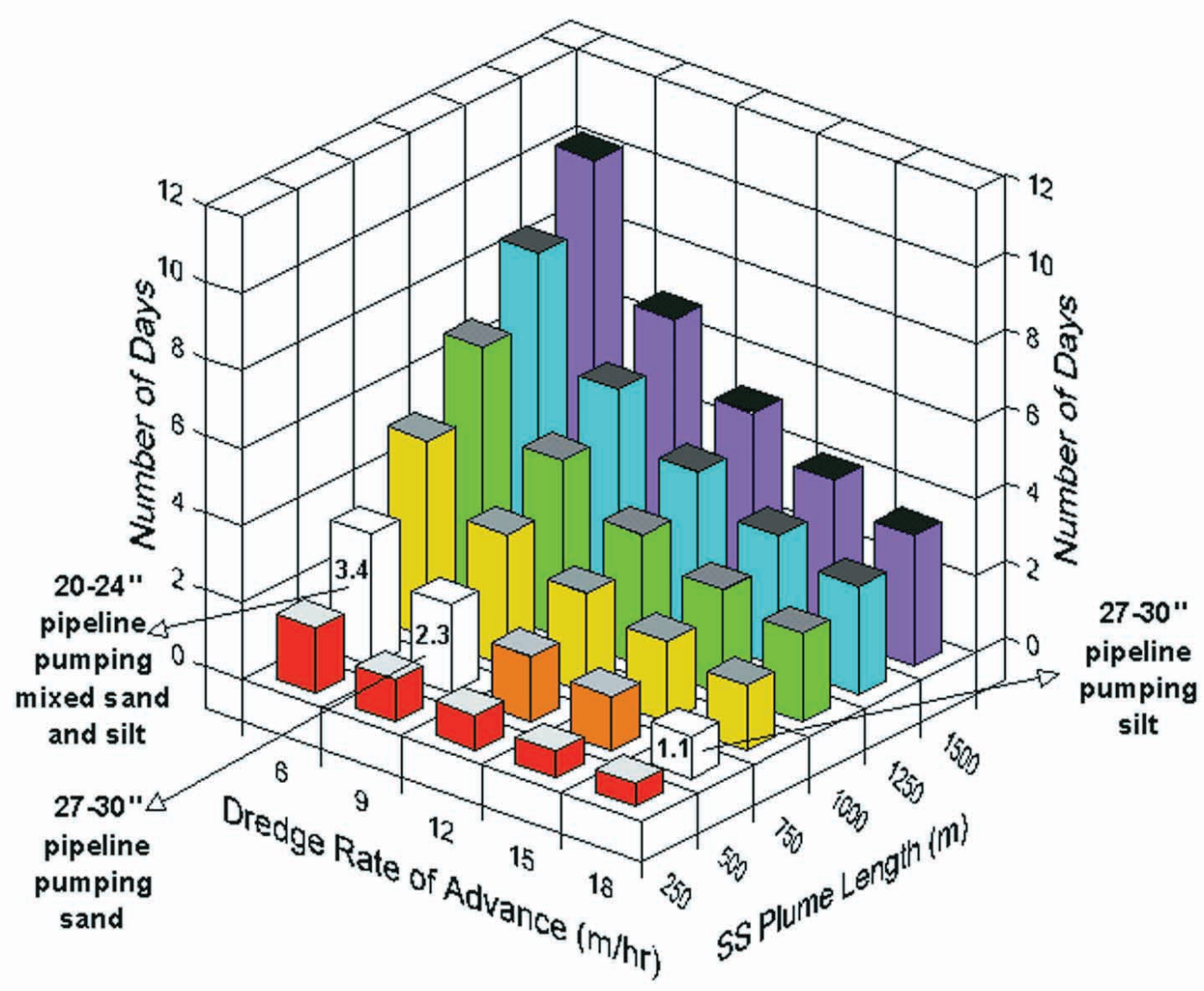

Figure 2. Range of exposure durations that may be experienced by sessile organisms as a suspendedsediment plume passes in association with a hypothetical hydraulic cutterhead dredging project. The white bars depict estimated exposure durations based on selected pipeline diameters and in situ sediment types

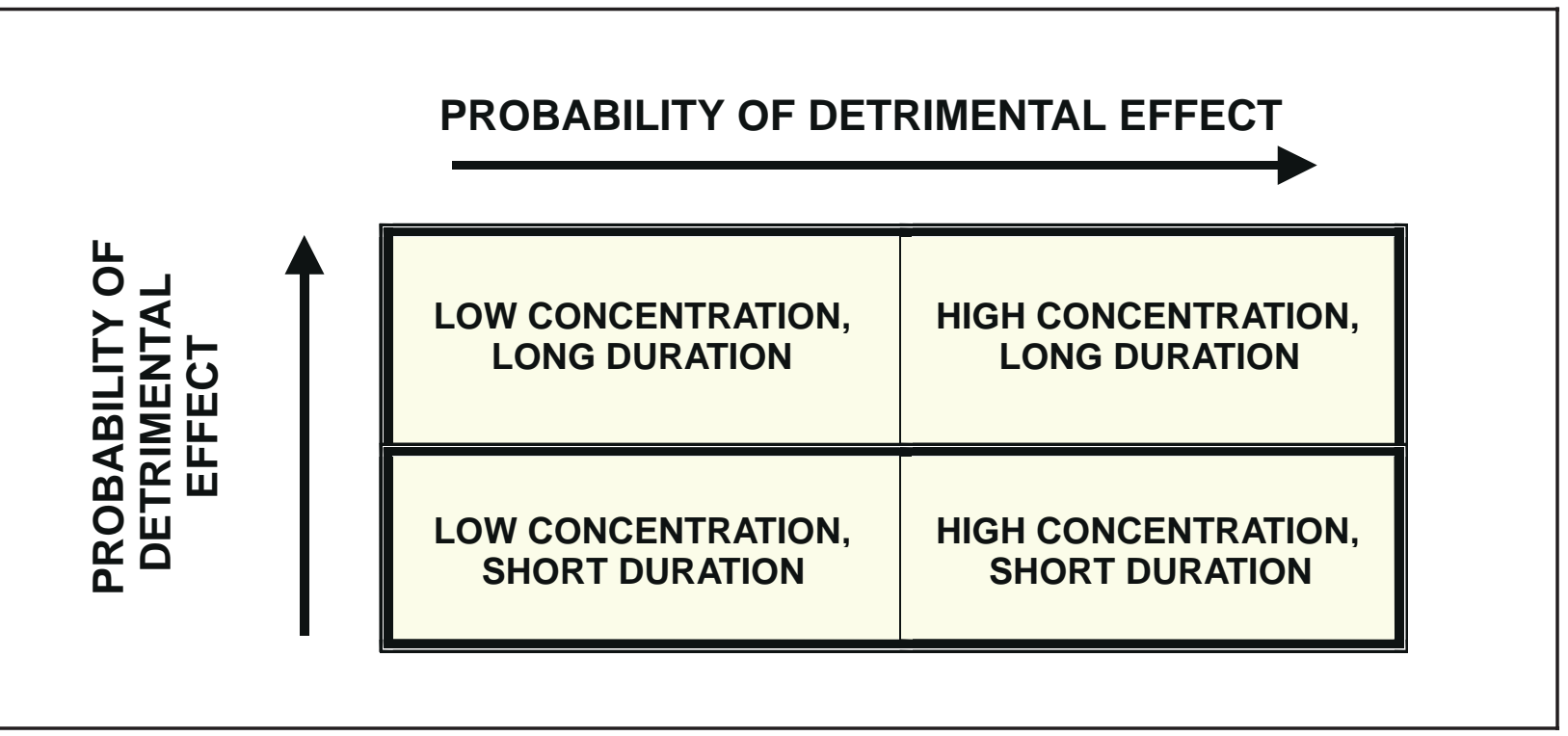

Figure 3. Categories of potential exposure to suspended sediments in the vicinity of a dredging operation 
thresholds. In contrast, projects generating persistent, high suspended-sediment concentrations represent the most problematic set of circumstances. Whereas acute exposures at high concentrations for short intervals of time might occur in association with many dredging project scenarios, these would often be limited in spatial scale. Perhaps the more difficult assessment involves exposures at low concentrations, but for extended durations, as might occur in restricted waterways. Nonetheless, placing the dredging operation accurately within the exposure matrix is a necessary first step in assessing probabilities of detrimental impacts.

This literature review brings to light the small number of species for which relevant data are available concerning biological responses to suspended-sediments within both the range of concentration and exposure durations associated with dredging projects. The prevalence of data come from bioassaytype tests that measure end points (usually mortality) under conditions that do not reflect what organisms are likely to encounter in the field. Most of the studies summarized in this review measured dose-response relationships under laboratory conditions that simulated a worst-case scenario for motile organisms subjected to continuous exposure. Motile organisms can generally avoid unsuitable conditions in the field. The effects of intermittent exposures to elevated suspendedsediment concentrations, which simulate conditions in many areas that are subject to tidal flushing, or are typical of hopper dredging operations (in which dredging is discontinued during transit to and from the placement site) are not addressed in the literature. Under most scenarios, fish and other motile organisms encounter localized suspended-sediment plumes for exposure durations of minutes to hours, unless the organism is attracted to the plume and follows its location. Fish eggs and larvae are more sensitive to suspended-sediment impacts than older life history stages; however, most of the available data for eggs and larvae pertain to freshwater conditions (Table 1). If a probable dredging-induced dosage of $\leq 1,500 \mathrm{mg} / \mathrm{L}$ for $\leq 1$ day is assumed for motile fishes (as indicated in Figure 1), documented detrimental impacts observed for juveniles and adults were limited to tests that used fuller's earth rather than natural sediments. Fuller's earth produces negative responses at lower concentrations than natural sediment (Sherk et al. 1974). Adult fish responses to suspended sediments for durations of less than 1 day at concentrations $\leq 1,500 \mathrm{mg} / \mathrm{L}$, i.e., conditions relevant to most dredging project scenarios, have not been sufficiently studied to reach definite conclusions.

For sessile organisms, exposure durations at a typical hydraulic cutterhead dredging site in the absence of tidal flushing are not likely to exceed 5 days (Figure 2), and in many cases may be substantially shorter. Although adult bivalve molluscs are silt-tolerant organisms (Sherk 1972), they can be affected by high suspended-sediment concentrations. Hard clams (Pratt and Campbell 1956) and oysters (Kirby 1994) exposed to fine silty-clay sediments have exhibited reduced growth and survival, respectively. Suspended-sediment concentrations required to elicit these responses and mortality, however, are extremely high, i.e., beyond the upper limits of concentrations reported for most estuarine systems under natural conditions and typical concentrations associated with dredging operations. Sublethal effects, such as reduced pumping rates and growth, were evident for adult bivalves at concentrations that occur under natural conditions, but may be of short-term (hours to days) duration, for example, during a storm (Schubel 1971; Turner and Miller 1991). As with estuarine fish, the egg and larval stages of shellfish are more sensitive to suspended-sediment impacts than the adults. Estimates of suspended-sediment impacts to these pelagic, early life history stages must consider the local hydrodynamics of the dredging site, which strongly influence the likelihood of extended exposure to suspended-sediment plumes. 
CONCLUSIONS: More than 20 years ago, the existing literature did not permit a "neat compilation and analysis" of the ecological consequences of dredging (Morton 1977). Despite continued concern and research in this area, particularly with respect to effects of suspended sediments, assessments of potential impacts on aquatic organisms remain highly subjective. Clearly, many past investigations focused upon detrimental effects induced by dosages well above those likely to occur at dredging project sites. Also obvious is the fact that appropriately designed studies to address dredging impacts are very limited in number and breadth of coverage, both with respect to taxa and life history stage. The lack of relevant data continues to foster controversy in impact assessments. Extrapolations from responses at inappropriate concentrations or exposure durations are widespread and engender interpretations rife with opportunities for false conclusions. Likewise, generic assessments of impacts based on responses across broad taxonomic lines should be viewed with extreme caution.

Until adequate data are available quantifying biological responses to appropriate concentration/ exposure duration dosages, assessment of potential dredging-induced impacts must unfortunately remain subjective. The authors endorse the construction of models (e.g., Newcombe and Jensen 1996) to integrate "best available knowledge" and to optimize objectivity in the assessment process. However, it is strongly recommended that any assessment consider not only the concentration threshold aspect of the dosage issue, but also realistic estimates of the likelihood and duration of exposure above that threshold. Tools to assist in this process are currently being developed under the Dredging Operations and Environmental Research Program, such as SSFATE, a numerical model customized for simulations of dredging-related suspended-sediment plume dynamics (see Johnson et al. 2000).

POINTS OF CONTACT: For additional information contact Dr. Douglas Clarke (601-634-3770, clarked@wes.army.mil), or the Program Manager of the Dredging Operations and Environmental Research Program, Dr. Robert M. Engler (601-634-3624, englerr@wes.army.mil). This technical note should be cited as follows:

Clarke, D. G., and Wilber, D. H. (2000). "Assessment of potential impacts of dredging operations due to sediment resuspension," DOER Technical Notes Collection (ERDC TN-DOER-E9), U.S. Army Engineer Research and Development Center, Vicksburg, MS. www.wes.army. mil/el/dots/doer

\section{REFERENCES}

Auld, A. H., and Schubel, J. R. (1978). "Effects of suspended sediment or fish eggs and larvae: A laboratory assessment," Estuarine and Coastal Marine Science 6, 153-164.

Boehlert, G. W., and Morgan, J. B. (1985). "Turbidity enhances feeding abilities of larval Pacific herring. Clupea harengus pallasi," Hydrobiologia 123, 161-170.

Bricelj, V. M., and Malouf, R. E. (1984). "Influence of algal and suspended-sediment concentrations on the feeding physiology of the hard clam Mercenaria mercenaria," Marine Biology 84, 155-165.

Bricelj, V. M., Malouf, R. E., and De Quillfeldt, C. (1984). "Growth of juvenile Mercenaria mercenaria and the effect of resuspended bottom sediments," Marine Biology 84, 167-173.

Cake, E. W., Jr. (1983). "Habitat suitability index models: Gulf of Mexico American oyster," FWS/OBS/-82/10.57, U S. Department of the Interior Fish and Wildlife Service, Washington, DC. 
Collins, M. A. (1995). "Dredging-induced near-field resuspended-sediment concentrations and source strengths," Miscellaneous Paper D-95-2, U. S. Army Engineer Waterways Experiment Station, Vicksburg, MS.

Davis, H. C. (1960). "Effects of turbidity-producing materials in sea water on eggs and larvae of the clam (Venus (Mercenaria) mercenaria)," Biological Bulletin 118, 48-54.

Davis, H. C., and Hidu, H. (1969). "Effects of turbidity producing substances in sea water on eggs and larvae of three genera of bivalve mollusks," The Veliger 11, 316-323.

Foster-Smith, R. L. (1976). "Some mechanisms for the control of pumping activity in bivalves," Marine Behavioral Physiology 4, 41-60.

Grant, J., and Thorpe, B. (1991). "Effects of suspended-sediment on growth, respiration, and excretion of the soft-shelled clam (Mya arenaria)," Canadian Journal of Fisheries and Aquatic Sciences 48, 1285-1292.

Grant, J., Enright, G. A., and Griswold, A. (1990). "Resuspension and growth of Ostrea edulis: A field experiment," Marine Biology 104, 51-59.

Gregory, R. S., Servizi, J. A., and Martens, D. W. (1993). "Comment: Utility of the stress index for predicting suspended-sediment effects," North American Journal of Fisheries Management 13, 868-873.

Havis, R. N. (1988). "Sediment resuspension by selected dredges," Environmental Effects of Dredging Technical Note EEDP-09-2, U.S. Army Engineer Waterways Experiment Station, Vicksburg, MS.

Hawkins, A. J. S., Smith, R. F. M., Bayne, B. L., and Heral, M. (1996). "Novel observations underlying the fast growth of suspension-feeding shellfish in turbid environments: Mytilus edulis," Marine Ecology Progress Series 131, 179-190.

Hecht, T., and van der Lingen, C. D. (1992) ."Turbidity-induced changes in feeding strategies of fish in estuaries," South African Journal of Zoology 27, 95-107.

Herbich, J. B., and Brahme, S. B. (1991). "Literature review and technical evaluation of sediment resuspension during dredging," Contract Report HL-91-1, U.S. Army Engineer Waterways Experiment Station, Vicksburg, MS.

Johnson, B. H., and Parchure, T. M. (1999). "Estimating dredging sediment resuspension sources," DOER Technical Notes Collection (TN DOER-E6), U.S. Army Engineer Research and Development Center, Vicksburg, MS. www.wes.army.mil/el/dots/doer

Johnson, B. H., Andersen, E., Tatsu, I., and Clarke, D. (2000). "Description of the SSFATE numerical modeling system," DOER Technical Notes Collection (ERDC TN-DOER-E10), U.S. Army Research and Development Center, Vicksburg, MS. www.wes.army.mil/el/dots/doer

Kerr, S. J. (1995). "Silt, turbidity and suspended-sediments in the aquatic environment: An annnotated bibliography and literature review," Technical Report TR-008, Ontario Ministry of Natural Resources, Southern Region Science and Technology Transfer Unit.

Kiorboe, T., Mohlenberg, F., and Nohr, O. (1981). "Effect of suspended bottom material on growth and energetics in Mytilus edulis," Marine Biology 61, 283-288.

Kiorboe, T., Frantsen, E., Jensen, C., and Nohr, O. (1981). "Effects of suspended-sediment on development and hatching of herring (Clupea harengus) eggs," Estuarine, Coastal and Shelf Science 13, 107-111.

Kirby, R. (1994). "Sediments 2 - Oysters 0: The case histories of two legal disputes involving fine sediments and oysters," Journal of Coastal Research 10, 466-487.

LaSalle, M. W. (1990). "Physical and chemical alterations associated with dredging." Proceedings, Workshop on the Effects of Dredging on Anadromous Pacific Coast Fishes, Seattle, WA, September 8-9, 1988. C. A. Simenstad, ed., Washington Sea Grant Program, Seattle, WA, 1-12.

LaSalle, M. W., Clarke, D. G., Homziak, J., Lunz, J. D., and Fredette, T. J. (1991). "A framework for assessing the need for seasonal restrictions on dredging and disposal operations," Technical Report D-91-1, U.S. Army Engineer Waterways Experiment Station, Vicksburg, MS.

MacDonald, D. D., and Newcombe, C. P. (1993). "Utility of the stress index for predicting suspended-sediment effects: Response to comment," North American Journal of Fisheries Management 13, 873-876. 
McLellan, T. N., Havis, R. N., Hayes, D. F., and Raymond, G. L. (1989). "Field studies of sediment resuspension characteristics of selected dredges," Technical Report HL-89-9, U. S. Army Engineer Waterways Experiment Station, Vicksburg, MS.

Messieh, S. N., Wildish, D. J., and Peterson, R. H. (1981). "Possible impact from dredging and spoil disposal on the Miramichi Bay herring fishery," Canadian Technical Report on Fisheries and Aquatic Science No. 1008.

Minello, T. J., Zimmerman, R. J., and Martinez, E. X. (1987). "Fish predation on juvenile brown shrimp, Penaeus aztecus Ives: Effects of turbidity and substratum on predation rates," Fishery Bulletin 85, 59-70.

Mohlenberg, F., and Kiorboe, T. (1981). "Growth and energetics in Spisula subtruncata (Da Costa) and the effect of suspended bottom material," Ophelia 20, 79-90.

Moore, P. G. (1978). "Inorganic particulate suspensions in the sea and their effects on marine animals," Oceanography and Marine Biology Annual Review 15, 225-363.

Morton, J. W. (1977). "Ecological effects of dredging and dredge spoil disposal: A literature review," No. 94, Technical Papers of the U.S. Fish and Wildlife Service, Washington, DC.

Mulholland, R. (1984). "Habitat suitability index models: Hard clam," FWS/OBS/-82/10.77, U.S. Department of the Interior Fish and Wildlife Service, Washington, DC.

Newcombe, C. P., and Jensen, J. O. T. (1996). "Channel suspended-sediment and fisheries: A synthesis for quantitative assessment of risk and impact," North American Journal of Fisheries Management 16, 693-727.

Newcombe, C. P., and MacDonald, D. D. (1991). "Effects of suspended-sediments on aquatic ecosystems," North American Journal of Fisheries Management 11, 72-82.

O'Connor, J. M., Neumann, D. A., and Sherk, J. A. (1976). "Lethal effects of suspended-sediment on estuarine fish,” Technical Paper No. 76-20, U. S. Army Engineer Coastal Engineering Research Center, Fort Belvoir, VA.

Pratt, D. M., and Campbell, D. A. (1956). "Environmental factors affecting growth in Venus mercenaria," Limnology and Oceanography 1, 2-17.

Priest, W. I. (1981). "The effects of dredging impacts on water quality and estuarine organisms: A literature review," Special Report in Applied Marine Science and Ocean Engineering, No. 247, Virginia Institute of Marine Science, Gloucester Point, VA, 240-266.

Robinson, W. E., Wehling, W. E., and Morse, M. P. (1984). "The effect of suspended clay on feeding and digestive efficiency of the surf clam Spisula solidissima (Dillwyn)," Journal of Experimental Marine Biology and Ecology $74,1-12$.

Schubel, J. R. (1971). "Tidal variation of the size distribution of suspended-sediment at a station in the Chesapeake Bay turbidity maximum," Netherlands Journal of Sea Research 5, 252-266.

Sherk, J. A. (1972). "Current status of the knowledge of the biological effects of suspended and deposited sediments in Chesapeake Bay," Chesapeake Science 13, 137-144.

Sherk, J. A., and Cronin, L. E. (1970). "The effects of suspended and deposited sediments on estuarine organisms: An annotated bibliography of selected references," Reference No 70-19, University of Maryland Natural Resources Institute, Solomons, MD.

Sherk, J. A., O'Connor, J. M., and Neumann, D. A. (1975). "Effects of suspended and deposited sediments on estuarine environments.” Estuarine Research 2. L. E. Cronin, ed., Academic Press, New York, 541-558.

Sherk, J. A., O’Connor, J. M., Neumann, D. A., Prince, R. D., and Wood, K. V. (1974). "Effects of suspended and deposited sediments on estuarine organisms, Phase II," Reference No. 74-20, Natural Resources Institute, University of Maryland, College Park, MD.

Turner, E. J., and Miller, D. C. (1991). "Behavior and growth of Mercenaria mercenaria during simulated storm events," Marine Biology 111, 55-64.

Urban, E. R., Jr., and Kirchman, D. L. (1992). "Effect of Kaolinite clay on the feeding activity of the eastern oyster Crassostrea virginica (Gmelin)," Journal of Experimental Marine Biology and Ecology 160, 47-60.

Urban, E. R., Jr., and Langdon, C. J. (1984). "Reduction in costs of diets for the American oyster, Crassostrea virginica (Gmelin), by the use of non-algal supplements," Aquaculture 38, 227-291. 


\section{ERDC TN-DOER-E9}

May 2000

Wakeman, T., Peddicord, R., and Sustar, J. (1975). "Effects of suspended solids associated with dredging operations on estuarine organisms." Ocean 75; Conference on Engineering in the Ocean Environment (Combined meeting of 1975 IEEE Conference on Engineering in the Ocean Environment and Eleventh Annual Meeting of the Marine Technology Society), San Diego, CA, September 22-25, 1975. Institute of Electrical and Electronics Engineers, New York, 431-436.

Widdows, J., Fieth, P., and Worrall, C. M. (1979). "Relationships between seston, available food, and feeding activity in the common mussel Mytilus edulis," Marine Biology 50, 195-207.

NOTE: The contents of this technical note are not to be used for advertising, publication, or promotional purposes. Citation of trade names does not constitute an official endorsement or approval of the use of such products. 